\title{
Are Black Colleges Producing Today's African-American Lawyers?
}

In past years, almost all of America's black lawyers came from historically black colleges and universities because these schools were the only ones that would admit black students. Today, it appears that black colleges are producing increasingly fewer of the nation's black lawyers.

\section{by Ronald G. Ehrenberg}

$\mathrm{O}$ VER THE YEARS historically black colleges and universities (HBCUs) have played a major role in educating African Americans seeking to enter the legal profession. Approximately 80 percent of our nation's African-American judges and 50 percent of its African-American attorneys were educated at HBCUs. But because major predominantly white universities opened their doors to blacks, a much smaller percentage of academically strong young blacks are matriculating at HBCUs. The question then is whether today HBCUs continue to play a leading role in producing graduates who go on to law school and become leaders in the legal profession.

\section{Black Applicants to Law School}

Statistical information on the undergraduate origins of recent African-American graduates of American law schools is not publicly available. However, the Law School Admission Services has provided unpublished data on the number of African-American law school applicants coming from top feeder schools for the past decade.

"Only 4 of the 176 ABA accredited law schools are located at HBCUs."

During the early 1980 s the top feeder schools were defined as the 370 colleges and universities that generated the largest number of African-American law school applicants. Seventy-six of these schools were HBCUs. Later, during the late 1980 s and early 1990 s, the top feeder schools were defined as the 240 institutions that generated at least 10 African-American law school applicants and 48 of these schools were HBCUs. These top feeder schools generated roughly 80 percent of all African-American law school applicants during the early 1980 s, but only about 70 percent during the late 1980s and early 1990s. Roughly 27 to 29 percent of the black applicants from the top feeder schools came from HBCUs in each period.

In the 1981 academic year 32.2 percent of all AfricanAmerican bachelor's degrees were awarded by HBCUs. Reflecting further integration of predominantly white institutions, this share fell to about 28 percent in 1994. Thus, HBCUs continue to produce African-American law school applicants at the same rate as their percentage of all African-American college graduates.

"Roughly 27 to 29 percent of black law school applicants come from $\mathrm{HBCUs."}$

Of course the number of students applying to law school from HBCUs does not necessarily equate with the number of students who are accepted, enroll, or complete law school. Because no data is available, one can only speculate about whether the number of law school applicants from HBCUs is greater or less than the number of HBCU students who graduate from law school. African Americans enrolled in HBCUs tend to come from lower socioeconomic backgrounds than other African-American college students. Financial pressures are more likely to limit the ability of these graduates from HBCUs to complete law school. Thus, the percentage of all law school applicants who graduate from HBCUs is in all probability less than the percentage of all law school graduates who came from HBCUs.

\section{Where Black Lawyers Earned Their Law Degrees}

Only 4 of the 176 American Bar Association accredited law schools are currently located at HBCUs. They are Howard, North Carolina Central, Southern, and Texas Southem. All of these law schools have a long history of producing African-American lawyers. In recent years these four $\mathrm{HBCU}$ law schools have produced between 10 and 17 percent of all new African-American lawyers. 


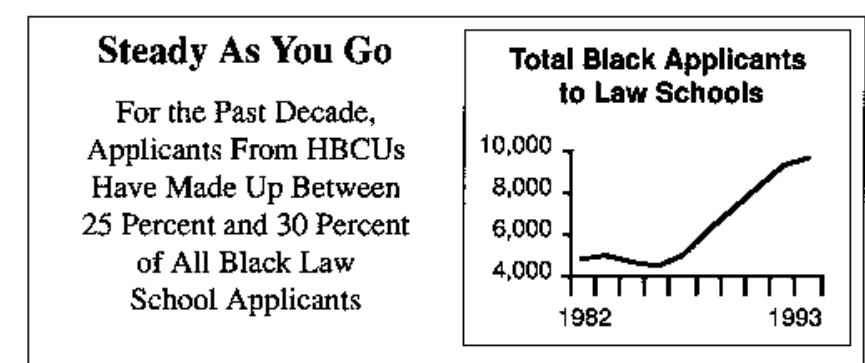

Percentage of All Black Law School Applicants From HBCUs

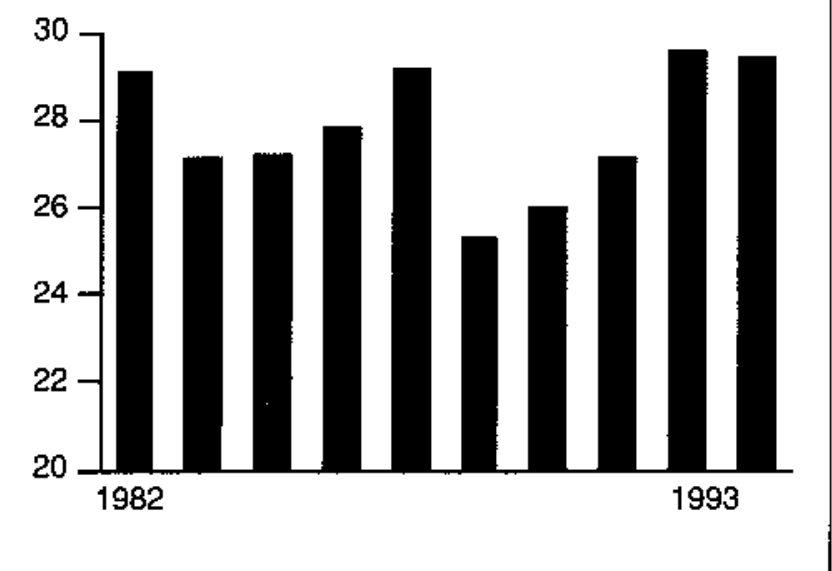

In the fall of 1993 approximately 12 percent of all AfricanAmerican law school students were attending HBCUs.

\section{The Success of Black Law School Graduates}

Contrary to what one might expect, the proportion of law school students who are African American is higher among first- and second-tier law schools than it is nationwide. And, as one would expect, it is the black graduates of these schools who tend to have the highest post-law school eamings. Graduates from the lowest tier of law schools are likely to earn the least. The HBCU law schools are all included in this lowest category.

However, postgraduation income is by no means the only, or even most, appropriate measure of success. Another way to judge a law school's success is to examine its record in producing leaders in a profession. One set of leaders in the legal profession is judges. Nationally 42.7 percent of the judges listed in Who's Who Among Black Americans, 1994-95 attended HBCU undergraduate schools, and 16.4 percent attended HBCU law schools. That is, as compared to their current enrollment shares, HBCU undergraduate and law schools have been "overproducers" of African-American judges.

Of course, many of the judges listed in this Who's Who Among Black Americans are nearing retirement. A more relevant question is the success of more recent graduates of HBCUs. When we confine the analyses to judges born after 1949 (who were age 45 and younger in 1993), only 27.9 percent received their undergraduate degree from HBCUs whereas only 4.8 percent received their law degree from HBCUs. Thus, at best, HBCU undergraduate schools are responsible for a proportionate share, and $\mathrm{HBCU}$ law schools for a less than proportionate share, of the younger African-American judges.

One can, however, do similar tabulations for the much larger sample of African-American attorneys listed in Who's Who Among Black Americans. Here, 35 percent of the more than 1,000 attorneys received their undergraduate degree from HBCUs and 20 percent received their law degree from HBCUs. For those born after 1949, the percentages fall to 21 and 10 percent, respectively. The percentages are about the same for those bom after 1954.

African-American lawyers who attended HBCU undergraduate or law schools during recent decades are somewhat less likely to make it into this Who's Who volume than African-American law school graduates from predominantly white institutions.

\section{Black Law School Faculty Who Graduated From HBCUs}

Another way to measure HBCUs' success is to focus on their role in producing African-American law school faculty members. The Association of American Law Schools (AALS) provided a list of all the full-time African-American faculty members employed by American law schools in 1993-9d Biographical information about each faculty member was then obtained from various sources. ${ }^{*}$ In all, the undergraduate institution of 482 , and the law school of 484 , of the 485 African-American full-time law faculty in 199394 were identified.

Approximately 17 to 18 percent of all full-time AfricanAmerican law faculty in 1993-94 had received their undergraduate degrees from HBCUs. However, if one limits one's view to faculty under the age of 41 , the range falls to 9 to 10 percent. Relative to the number of undergraduate

*These sources include the 1993-94 AALS Directory of Law Teachers, various law school catalogs, telephone calls to deans' offices and to faculty members at a number of law schools, information contained in law review articles that several faculty had authored, Bowker's biographical directories, and a mail survey conducted in June 1994 of black law school faculty. 
students who they appear to send on to law school, $\mathrm{HBCU}$ undergraduate institutions are currently "underproducers" of African-American law school professors.

If one repeats the analyses separately for each quality tier of law school, a striking pattern emerges. On balance, the lower the tier of law schools, the higher the probability that the African-American law professors came from undergraduate HBCUs. For example, less than 5 percent of the national total of 87 African-American law professors employed at first-tier schools received their undergraduate degrees at HBCUs. Moreover, of the 29 full-time faculty age 41 and under at these first-tier law schools, none received an undergraduate degree at an HBCU.

To the extent that law professors at the top-ranked institutions can be considered the leaders in their field, an undergraduate degree from an HBCU does not appear to be a ticket to success. Indeed, even if one aspires to teach at an $\mathrm{HBCU}$ law school, attending an HBCU undergraduate school does not appear to be the way to get there. The proportion of young African-American faculty at HBCU law schools who received their undergraduate degree at HBCUs, 20 percent for all faculty and 16.7 percent for professorial faculty, is substantially below the proportion of African-American law school applicants that HBCUs generate.

About 10 percent of black faculty of all ages and slightly less than 5 percent of African-Amcrican law faculty age 41 and younger attended an HBCU law school. Both of these numbers are below the 12 to 17 percent of African-American law school graduates that the four HBCU law schools have produced in recent years. Moreover, although there are almost 100 African-American faculty age 41 and younger with regular professorial appointments in the top three tiers of law schools in 1993-94, only one received a law degree from an HBCU law school.

\section{Conclusions}

Several themes emerge from this analysis. First, HBCUs remain an important source for the undergraduate and law school educations of African-American lawyers and judges. However, it is no longer the case that a majority of AfricanAmerican lawyers are educated at the HBCUs. Second, African-American lawyers who recejved thcir undergraduate degree from HBCUs are significantly underrepresented

\begin{tabular}{|c|c|c|c|c|}
\hline $\begin{array}{r}\text { Blacks as a Per } \\
\text { Faculty Ra }\end{array}$ & $\begin{array}{l}\text { entage of } \\
\text { ked by } Q\end{array}$ & $\begin{array}{l}\text { Law Sch } \\
\text { uality of } 1\end{array}$ & $\begin{array}{l}\text { ol Stude } \\
\text { aw Sch }\end{array}$ & $\begin{array}{l}\text { nts and } \\
\mathrm{ol}^{*}\end{array}$ \\
\hline Law School Rank & $\begin{array}{l}\text { Black } \\
\text { Students }\end{array}$ & $\begin{array}{l}\text { \% Elack } \\
\text { Students }\end{array}$ & $\begin{array}{l}\text { Black } \\
\text { Faculty }\end{array}$ & $\begin{array}{l}\text { \% alack } \\
\text { Faculty }\end{array}$ \\
\hline First Tier & 1,929 & $8.8 \%$ & 102 & $4.8 \%$ \\
\hline Second Tier & 1,606 & 8.5 & 75 & 4.8 \\
\hline Third Tier & 1,487 & 5.9 & 123 & 6.1 \\
\hline Fourth Tier & 1,483 & 5.2 & 87 & 3.9 \\
\hline Fifth Tier & 1,362 & 5.8 & 106 & 6.1 \\
\hline HBCUs** & 1,075 & 61.1 & 93 & 62.4 \\
\hline Total & 8,942 & 7.4 & 586 & 6.0 \\
\hline $\begin{array}{l}\text { Law schools separat } \\
\text { World Report. } \\
\text { *Figures for law sch } \\
\text { ifth-lier schools whe }\end{array}$ & $\begin{array}{l}\text { d into ticrs b } \\
\text { ools at } \mathrm{HBCl} \\
\text { e they noma }\end{array}$ & $\begin{array}{l}\text { y rankings tis } \\
\text { Is are exclud } \\
\text { Jly would be }\end{array}$ & $\begin{array}{l}\text { ed in U.S. } \\
\text { d from sta } \\
\text { ncluded. }\end{array}$ & $\begin{array}{l}\text { News \& } \\
\text { istics for }\end{array}$ \\
\hline
\end{tabular}

among the faculty of our most selective law schools. Finally, African-American lawyers who received their law degree at HBCUs are much less likely to attain faculty appointments at our nation's top-ranked law schools than are African-American lawyers who received their advanced degree from predominantly white institutions.

Attendance at a top-ranked law school is not the only route to professional success. Nor is a faculty position at a top-ranked law school necessarily the best way to serve the African-American community. Nevertheless, one must place value on increasing the diversity of faculty at major American law schools in order to provide more hospitable environments for underrepresented minority students at these institutions. From this viewpoint, the underrepresentation of graduates of HBCUs among African-American faculty at these institutions is disturbing. Hence, strategies must be developed by law schools to increase the flow of graduates from HBCUs into law degree programs at selcctive American universities and then on to faculty positions at the sclective law schools.

IAET:-

Ronald (j. Ehrenberg is vice presiden for academic programs. planning and bidgeting, and Wing M. Thes Professon of Industrial and Labor Relations and Ecomomics at Cornell University. Researth stoport was prouided by grants from the Andrew' W. Mellon and William $H$. Downes foundations. The vieus expressed here are solely the author's. Credit also goes to Jason Ehrenberg. currenty a law student at the Unitersity of Michigan, and to Alherivme Harris of the Cormell Class of 1998 for their resear h assiswance. A more detaited verwion of this articte with detailed rables, notes. and references is available m the Wortd Wide Web at w'n'n'ipricomell.edn. 